\title{
Movement of Indigenous Communities Targeting an Agro-industrial Investment in North-eastern Cambodia
}

\author{
Sokphea Young \\ The University of Melbourne
}

\begin{abstract}
This study examines the dynamics and outcomes of movements by indigenous communities that targeted an agro-industrial investment demanding remedy to adverse impacts on their socio-economic conditions. Since the employment of initial institutional tactics, such as peaceful protests and petitions, yielded no significant outcomes, the indigenous communities escalated their tactics to non-institutional tactics: Violent protests. To respond, the government chose a combination of partial repression and moderate concession. To address the government responses, as well as the demands of indigenous communities, the company mitigated most of the adverse socio-economic impacts. As a result, the indigenous communities were able to achieve most of their demands. This paper, therefore, concludes by arguing that tactical escalation of indigenous community movements from institutional to non-institutional tactics influences the government and company to address the demands of indigenous communities, and also shapes the behaviour of the company operating in a host country with lax and uncertain regulatory enforcement.
\end{abstract}

\section{Keywords:}

indigenous communities, movement, (non-) institutional tactics, mechanisms of response, rubber, movement's outcomes

\section{Introduction}


In the era of globalisation, capital of foreign companies is being attracted to a number of developing countries due in part to increasing demands of the consumer market, the potential for lower cost of production, and the existence of unexplored natural resources in host countries (Moser, 2001). For these reasons, Cambodia has increasingly attracted a huge number of foreign companies since the late 2000s (Ngov, 2011). In the agricultural sector alone, the capital increased remarkably from US\$27 million in 2005 to US\$446 million in 2009 (CDC, 2010). This was because the government of Cambodia issued a sub-decree on Economic Land Concessions (ELCs) to attract foreign investors (RGC, 2005). Through ELCs, both domestic and foreign investors gained access to land leases of up to 99 years. A number of these investors were reported to have gained access to ELCs because of strong ties and joint ventures with local powerful politico-commercial elites, high-ranking officials and politicians of the ruling government (Global Witness, 2007; ADHOC, 2013). As of late 2012, at least 2.6 million hectares of land were granted to both domestic and foreign companies (ADHOC, 2013), which aimed to generate economic growth, employment and reducing poverty in rural communities (RGC, 2005). However, these investments, though not all, have repeatedly been accused of deteriorating social, economic and environmental conditions of the marginalised communities. Despite the obvious adverse impacts, these investments have survived because of, as mentioned above, the establishment of joint ventures with political elites who facilitate their operations (Un, 2009). In reaction to these, a number of communities, including indigenous communities in north-eastern Cambodia, mobilised against foreign joint venture companies' operations and the Government of Cambodia.

This study aims to investigate movements of indigenous communities targeting a foreign joint venture company's investment in rubber plantations in a north-eastern province of Cambodia. It explores the dynamics of movements, responses of the government and joint venture company, and the outcomes of those movements. In so doing, a within-case process tracing method was employed. The method involves "the detailed examination of an aspect of a historical episode to develop or test historical explanations that may be generalisable to other events" (George and Bennett, 2005: 5). Given the communities' historical episodes and characteristics, which represent an important contribution to the current theoretical debate pertaining to the effect of social movement's non-institutional and institutional tactics, movements of indigenous communities in Bousra commune, Pich Chreada district of Mondulkiri Province were selected for empirical observation. In addition to a literature 
review (reviewing related articles, documents, reports, etc.), the study conducted semistructured interviews with 16 key informants, ${ }^{1}$ and held two focus group discussions, in which ten villagers from a different background were invited to participate in each interactive discussion.

As a result of within case empirical analysis, this study argues that: (i) tactical escalation of indigenous community action, from institutional to non-institutional tactics, does have significant influence on the government and company to moderately concede to and address most of indigenous communities' demands; and, to a certain degree, (ii) the movement of indigenous communities shapes corporate behaviour of a foreign company operating in a host developing country with lax and uncertain regulatory enforcement. These provide significant implications for contemporary debate pertaining to tactical influence of (new) social movement studies, the dynamics and outcomes of movements, which involve tripartite actors, and politics of the Government of Cambodia dealing with movements of aggrieved groups.

To unpack these arguments, the remainder of the paper is divided into six sections. The first reviews theoretical frameworks that underpin movements of indigenous communities in this case. This is followed by the discussion of historical, cultural and political contexts of indigenous communities in the second section, the third section discusses the tactics of a movement, including non-institutional and institutional tactics of the indigenous communities, and their expected outcomes (demands). The fourth section then analyses the mechanism of the government and company towards the indigenous communities. The fifth section recaps the outcomes of movements of indigenous communities by comparing the demands versus actual outcomes. Last, but not least, the sixth section summarises and concludes the dynamics and outcomes of movements, and draws implications of the movements.

\section{Theoretical concepts underpinning movement of indigenous communities}

To understand how tactical employment determines outcomes of a movement (Gamson, 1990; McAdam, 1983), it is worth reviewing theoretical concepts of (new) social movement 
that underpin movements of the indigenous communities, their targets and influencing tactics, responses of government and companies (corporations), and outcomes of movements.

\section{(New) social movement}

A social movement is meant to affect change of particular things in society, and is usually conducted by a group of people with a particular and common interest and goal (Wilson, 1973; Tilly, 1978). This underpins several theoretical concepts of social movements, such as classical or old social movements, resources mobilisation, and political process. Unlike these concepts, new social movements emerge to address contemporary issues of industrialisation.

A New Social Movement (NSM) pays more attention to "why", rather than "how" social movements mobilise (Klandermans and Tarrow, 1998). NSM theories emerge in response to the narrowly-defined classical Marxism for analysis of collective action that is based on relations of production and social class (Buechler, 1995). In spite of the different emphasis of NSM (Buechler, 1995), this study is influenced by modernisation or postindustrial society concepts since it provides implications to the present indigenous movement in Cambodia. For instance, NSM is a result of modernisation that causes conflicts, and provokes a more defensive kind of resistance (or protest in particular) against the side-effects of modernisation, such as economic, technological or political changes (Rucht, 1988). Though NSM seems to be well defined, Hall (1995) contends that NSM seems to divert scholars' attention away from political process, and fails to define how organisations are formed, how an aggrieved group connects to collective action, and how organisational structure affects the types and forms of collective action; this is also clarified by Pichardo (1997) in terms of tactics and structures.

In terms of structures, NSM tends to organise itself as an ad hoc organisation, and their leaderships are rotated and voted on communally. NSM adapts to an anti-bureaucratic attitude, in which it organises itself in a more flexible way to avoid oligarisation structure (Offe, 1985). In this sense, it creates its own structure that is more responsive to the needs of individuals but is with an open, decentralised and non-hierarchical structure (Zimmerman, 1987, cited in Picardo, 1997). In terms of tactics, NSM uses anti-institutional tactics, but they prefer to remain outside formal political channels, and makes use of public opinion and disruptive tactics to leverage influence (Tarrow, 1994). Overall, there is no truly distinct 
tactical style of NSM. Although public opinions and anti-institutional politics have been prominent tactics (Pichardo, 1997), these somehow overlap with tactics of other social movements, which can be conceptualised to analyse a movement of indigenous communities in this study.

\section{Tactics and targets of movements}

In NSM scholars suggest several kinds of influential tactics; for instance, institutional versus non-institutional action, legal versus illegal action, and violence versus non-violence (Marx and McAdam, 1994; McAdam and Tarrow, 2000); as well as non-disruptive and disruptive tactics (Cress and Snow, 2000; Gamson, 1990; Giugni, 1998). These tactics are similar and known as institutional and non-institutional tactics. While institutional tactics, such as peaceful protest, petition, filing complaint, rallies and other forms of non-violence, tend to be legal (Cress and Snow, 2000), non-institutional tactics, such as violent protest, sit-ins and any harmful activities, are deemed as illegal. Though these tactics are clearly conceptualised, the extent to which these tactics leverage influence the most to achieve a movement's demands remains contested (Stephan and Chenoweth, 2008). Meanwhile, other scholars argue that not only the tactical employment per se, but also the selection of the target is imperative to leveraging influence and attaining the outcomes of a movement. Having understood the vulnerability of the targets, the better chance a movement has of succeeding (Van Dyke et al., 2005). Due to these contested arguments, this study, however, observes how the indigenous communities employ both non-institutional and institutional tactics to leverage influence.

Although targets of NSM remain debated (Schurman, 2004; Van Dyke et al., 2005; Wood, 2004), Soule $(2009,2012)$ contends that the targets of a movement can be both a government/state and a corporation. In the past, movements more often than not targeted governments or states, but in the era of globalisation and increasing corporate power, the target of movements turns to companies or corporations (Soule, 2009). Yet, this study believes that at least one government is a claimant - an object of claim or a party to claim (McAdam et al., 2001). So, the government may act as a mediator or regulator (Soule, 2009). For instance, Walker et al. (2008) argue that government has stronger capabilities not only to regulate corporations, but also to address hostile groups' claims when a contention involves three actors (government, corporations and movement organisations). In this study, the 
company is deemed as a primary and an ultimate target, while the government as a secondary target. However, the government is perceived to possess stronger power in mediating contention between indigenous communities and the company.

\section{Government and corporations responses}

In response to a movement, according to Goldstone and Tilly (2001), a government may opt for any of the four modes of response: tolerance, concession, repression, or a combination of repression and concession. Further to Goldstone and Tilly's (2001), Cai (2010) similarly defines that: (i) concession - a movement succeeds as the demands are fully addressed; (ii) concession with discipline - a movement's demands are addressed but some or all protesters are punished; (iii) tolerance - a movement's demands are ignored or tolerated; and (iv) repression - a movement's demands are ignored and some or all protesters are published. However, neither Cai (2010), nor Goldstone and Tilly (2001) define in what way a government concedes. When a movement involves three actors, the study endorses Soule's (2009, 2012) argument that, in the age of increasing corporate power, a government is involved as an intermediary or a regulator. In essence, this study defines a mechanism of government's concession as a process of regulating the corporations to address the demands of movements. By regulating, it means the process of (re-) enforcing relevant regulations to regulate corporations operating in a host or a country's jurisdiction. The enforcement can be escalated, to borrow from Ayres and Braithwaite (1992), from persuading, warning, monetary penalising, and criminal complaining to suspending and revoking of licenses. This may compel the corporations to address the demands of a movement or to comply with the government's intervention.

As mechanism of response to either the government or movements, this study postulates that corporations have two options, regardless of other mode of corporations' response policies. First, if the contention involves a government as an intermediary, once the government concedes the corporations have to comply with government's concession to address the demands of a movement. Second, if government does not concede, corporations simply ignore the demands of a movement ( $c f$. Soule, 2009). Otherwise, if movements turn to target corporations directly, and successfully threaten corporations' revenue portfolio and reputation, corporations may concede by changing their policies to address movements' 
demands (King, 2008). Influenced by these, the study observes how the company concedes by changing its behaviour, and complying with the concessions of the government and the protests of the indigenous communities.

\section{Defining outcomes of movements}

The ultimate goal of a movement is to bring about positive change as an outcome. Yet, the definition of success or failure outcome of movements is elusive, since the extant literature of social movements have generally paid less attention to outcomes (Giugni, 1998). If the outcomes are emphasised, scholars tend to focus on broad aspects, such as political, economic, social, cultural and policy changes (Cai, 2010; Cress and Snow, 2000; Giugni, 1999; Marx and McAdam, 1994). To generalise outcomes, other scholars suggest two important types of outcomes: direct outcomes, including securing constituent benefits and achieving new advantages from the target (Burstein, 1999; Gamson, 1990; Isaac and Kelly, 1981); and indirect outcomes, including public perception, biographical changes (Gusfield, 1984; McAdam, 1988), cultural changes and institutional effects lately (Giugni, 1998). While direct outcomes are simply defined as goals or demands of movements, indirect outcomes are claimed as unexpected consequences generated from indirect influence of movements (Cress and Snow, 2000). Influenced by these, this study aims at investigating direct outcomes, which are about remedying adverse socio-economic impacts on the indigenous communities. Though success or failure outcome of a particular movement remains contested (Gamson, 1990; Steedly and Foley, 1979), the study understands that movements succeed when their demands are fully or moderately addressed by the targets, and they fail otherwise. Regardless of the several theoretical factors that underpin success or failure of a movement claimed by McAdam (1999), Tarrow (1998), Tilly (1978), Goldstone and Tilly (2001) and Cai (2010), this study perceives that tactical influence, as argued by McAdam (1983) and Gamson (1990), is a major factor contributing to success or failure of a movement.

\section{Cultural and political contexts of indigenous communities in north-eastern Cambodia}

In order to analyse movements of indigenous communities, their demands and expectations, and their interactions with the government and company, it is necessary to understand their 
political, cultural and historical contexts. Politically and historically, north-eastern provinces of Cambodia, especially Ratanakiri and Mondulkiri provinces, used to be the first Khmer Rouge's strongholds where they mobilised indigenous communities to resist the government in the late 1960s (Colm, 1996; Baird, 2008). During the control of the Khmer Rouge from 1975 to 1979, some of indigenous communities who did not join the Khmer Rouge relocated themselves to the border of Vietnam. They returned back after the collapse of Khmer Rouge in late 1979. Since the mid-1980s until the present, the indigenous people have re-established their relationship with the government ruled by Cambodian People's Party. They have, however, struggled with legal status and their traditions.

Coupled with change in Cambodia's political system from communism (1980s) to democracy (1990s), the indigenous communities in the north-eastern provinces have legally drawn attention of the ruling party. In pursuit of ruling party's political interests, related regulations and laws were adopted to support the indigenous communities. In 2001, the Land Law was adopted by the government to formally recognise indigenous communities' collective land or properties ownership (Keating, 2013). Following that, the Forestry Law of 2002 also recognises the rights of the indigenous communities that are registered by the state. In 2009, the government issued a sub-decree on Procedures of Registration of Land of Indigenous Communities. These two laws and a sub-decree require the indigenous communities to register their collective land ownership in order to secure communal land titles (see Footnotes 5 and 6). So far, a few out of the hundred indigenous communities in the north-eastern provinces have successfully registered their communal land title (Milne, 2013). Besides the lack of financial support, the remaining communities have struggled with the complex and bureaucratic land registration system of the government.

Culturally, for centuries the indigenous communities in the north-eastern provinces have had a distinct culture from the Khmer people. This includes, for example, their language, agricultural practices, religious practices and organisational relations within their communities. Their agricultural practices are based on a rotational form of cultivation, which relies on slash-and-burn of the forest to establish a cultivatable field for a few years, and then moving to another location before returning back to the previous one. Their livelihoods are based on natural resource products, including non-timber forest products (NTFPs) (e.g., resins, vegetables, mushrooms, honey rattan, bamboo shoots, etc.). Though their religious practices are ascribed as animist, a number of indigenous people have converted to 
Christianity and Buddhism. Despite such conversion, a large number of communities still worship forest and their ancestors' cemeteries. As a result of regionalisation and an increase in the penetration of a cash economy into the north-eastern areas, indigenous people's ways of barter have recently transformed from goods exchanges to cash payments. This has prompted the indigenous people's desires and needs for money, for which it causes social problems, such as internal conflicts, theft, selecting marriage partners, etc. (Backstrom et al., 2007).

Given their rich soil fertility and natural resources, the north-eastern provinces have since the late 1990s attracted a cash crop economy. Some of the indigenous people's farms have been converted into cash crop plantations, such as cashew nuts, rubber, mangoes, jackfruit, avocadoes, cassava and other perennial cash crops. These generated addition income and also substituted the seasonal rice shortage of the indigenous communities. Medium-scale plantations of such cash crops have increasingly flourished in these indigenous communities' areas (Backstrom et al., 2007). Since the early 2000s, with a significant increase in the demand for agricultural products, the north-eastern provinces (Kratie, Steng Treng, Mondulkiri and Ratanakiri) have attracted a number of large-scale foreign and domestic investments. These large-scale land investments, including mining, logging and agro-industrial concessions are reported to have linked with politico-commercial elites and officials of the ruling party (McAndrew and IL, 2009). Since related regulations (prior consultation and consent, impact assessments) have not been enforced properly by the government, and well complied with by the investors, these investments have caused adverse effects on cultural, socio-economic and environmental aspects of the indigenous communities in these north-eastern provinces.

\section{A movement of indigenous communities in north-eastern Cambodia: Causes and demands}

Home to a number of indigenous communities, including the Bunong (Phnong), Kren, Jaray, Krorl, Steang, Khmon, Kouy and Tumpoun, to name a few, Mondulkiri province has attracted a number of foreign joint venture companies. In 2005, the government started granting Economic Land Concessions (ELCs) to both domestic and foreign companies to invest in rubber or other cash crop plantations. As of May 2012, 15 ELCs were awarded by 
the government. These ELCs extend on the total area of approximately 94,731 hectares, which are mostly located in Bousra and Krang Teh communes of Pich Chreada district. In Bousra commune, two companies among others (namely, Apple and Orange) ${ }^{2}$ were granted ELCs in 2008. Apple was awarded about 3,000 hectares, and Orange was awarded about 4,500 hectares, respectively for a 70-year concession period. After almost a year of land preparation, a Belgium company, namely Sophia, ${ }^{3}$ in a joint venture with Cambo, a local company, took over the management and operation of the two ELCs. Sophia holds $70 \%$ and Cambo owns the rest of the shares. Currently, these two ELCs are operating in the name of Sophia-Cambo (the company, hereafter). The owner of Cambo is known as a tycoon holding the title of Oukna (wealthy person), which is bestowed by the King at the request of the government once he or she contributes about US\$100,000 to national development, and as a private advisor to the Prime Minister (FIDH, 2011). Evidence suggests that, though the owner of Cambo is an Oukna, he is not an active politician, nor a financial sponsor of the ruling party, the Cambodian People's Party, when compared to other tycoons. Yet, this relationship could facilitate access to ELCs and long-term operation of the rubber plantation.

With a total population of 1,063 households (equivalent to 4,810 people), Bousra commune consists of seven villages. The majority of them are indigenous people (Phnong). As explained in the previous section, their livelihoods are based on agricultural production, such as shifting cultivation and lowland rice cultivation; collecting NTFPs: resin, honey, bamboo or bamboos shoot, vine, rattan, wild fruits and vegetables; cash crop plantations, including beans, cashew nuts and sesame; and livestock raising. In early 2008, the indigenous communities were surprised and shocked as the company cleared not only indigenous people's farmland, but also vacant land and (worship) forestland, cottages, and other crop plantations. These caused adverse effects on the socio-economic conditions of about 850 families (FIDH, 2011). As a result, tension between the company and the affected indigenous communities (AIC, hereafter) erupted. In the same year, the AIC launched several kinds of collective action seeking to influence the government and company to remedy the unfavourable impacts. In particular, the AIC demanded that the government and company:

\footnotetext{
2 All names are pseudonyms, which are given to comply with research ethics and consent made between the researcher and participants from the company.

3 Registered in Luxembourg, Sophia is owned by French industrial group and Belgian families. The company has also joined UN Global Compact for Corporate Social Responsibility (FIDH, 2011).
} 
1. Conserve the remaining cemetery and worship forests, and celebrate sacrificed ceremony. As above, the Phnong is one of the indigenous communities who worship forests and cemeteries. They believe that the spiritual forest protects them from having sickness, disaster and encroachment of evil;

2. Return farmland or otherwise pay a fair cash compensation. The company cleared and damaged the indigenous communities' traditional agriculture, such as shifting farming, farmland and other plantations. Around 1,500 hectares of the AIC's plantations were lost to the company. This worsened their livelihood; ${ }^{4}$

3. Remedy the loss of income from collecting NTFPs. With the endorsement of the government, the company cleared forestland where indigenous communities used to collect NTFPs for selling after daily consumption. This caused adverse effects on communities' livelihood and income;

4. Re-comply with relevant regulations. The company contravened the rights to collective ownership of indigenous communities, which are stated in Articles 23 to 28 of the 2001 Land Law, and Article 37 of the 2002 Forestry Law ${ }^{5}$ and

5. Respect land rights of the indigenous communities. The government and companies violated indigenous communities' collective properties, shifting cultivation, other forms of traditional agricultural activities and worship sites of the indigenous communities. These collective properties are recognised by the 2001 Land Law, and the Sub-decree on the Procedures of Registration of the Land of Indigenous Communities. ${ }^{6}$

$4 \quad$ P11 (see the Appendix).

$5 \quad$ Article 37 of the Forestry Law (2002) requires concessionaires to make sure their operations do not interfere with the "Customary user rights taking place on land property of an indigenous community that is registered with the state consistent with the Land Law; and customary access and user rights practiced by communities residing within, or adjacent to forest concessions." The company also violated other international conventions rectified by the Government of Cambodia, yet this is out of scope of this paper.

6 According to Article 23 of the Land Law (2001), an indigenous community is defined as "a group of people that resides in the territory of the Kingdom of Cambodia whose members manifest ethnic, social and cultural and economic unity and who practice a traditional lifestyle, and who cultivate the lands in their possessions according to customary rules of collective use.” 
As defined in the theoretical section, a movement of the AIC succeeds only if the above demands are fully or moderately addressed by the government and company. To influence the government and company, the AIC orchestrated both institutional and non-institutional tactics.

\section{Tactical influence of the affected indigenous communities}

To influence the government and company to address their demands, the AIC launched two stages of mobilisation. Corroborating to theoretical concepts, the indigenous communities initially employed institutional tactics, such as petitions, peaceful protest, and targeting the government in hopes of influencing and regulating the company.

\section{Institutional tactics}

In April 2008, as the company began to clear plantations, cemeteries and worship forest, the AIC consulted with village heads and the latter submitted a petition to commune and district offices to seek intervention. On several occasions, ${ }^{7}$ the commune and district offices could not postpone the company's activities. In May 2008, about a hundred representatives of the AIC protested at the provincial office of Mondulkiri to seek intervention from provincial governors, as well as provincial sectoral (agriculture, environment, land) departments. Again, no significant result was offered, though National Authorities for the Resolution of Land Disputes intervened, they just provided empty promises. Later, in October 2008, the representatives of the AIC filed petitions regarding the adverse impacts caused by the company's operations with the Councils of Ministers, the Ministry of the Interior (MoI), and the Ministry of Land Management, Urban Planning and Construction in Phnom Penh. The AIC claimed that there was no immediate response or any intervention undertaken by these concerned institutions.

In addition to the above, a number of local $\mathrm{NGOs}^{8}$ were involved in mediating the dispute, and investigating the detrimental impacts. On behalf of the AIC, the local NGOs

\footnotetext{
$7 \quad$ P08 (see the Appendix).

8 Community Legal Education Centre, ADHOC, Caritas, My Village, and Indigenous Communities Support Organisation, to mention a few.
} 
jointly submitted a number of legal memoranda to the government and the company to seek solutions. The local NGOs furthermore provided legal advice and trainings to empower the AIC. Though a number of representatives of the indigenous communities were selected to be spokespersons in the seven villages of Bousra commune, they were not confident in the NGOs. The spokespersons perceived that the NGOs just came to console them, not to take serious action while their land was being confiscated without due reason. ${ }^{9}$ Having perceived that institutional tactics yielded no result, they then escalated to non-institutional tactics.

\section{Tactical escalation from institutional to non-institutional tactics}

Tactical escalation typically involves dramatic or innovative instruments, as well as provocation that tests the vulnerabilities of one's foe (O'Brien and $\mathrm{Li}, 2006)$. It is usually staged by protesters to exert extra pressure on their foes since the protesters' previous influential tactics did not work. In this case, as the institutional tactics produced no satisfactory result and influence, as claimed by Stephan and Chenoweth (2008), the AIC escalated to non-institutional tactics (violent protest) to leverage harmful pressure directly on the company and indirectly on the government.

On 20 December 2008, after gathering at the commune office, about $500^{10}$ indigenous people were outraged and marched with sticks, axes, bottles of gasoline, lighters, knives, etc. ${ }^{11}$ from the commune office to the concession areas, where a number of bulldozers were clearing worship forestland, and indigenous people's plantations and farmland. As the crowd of protesters arrived, the company's bulldozers fearlessly continued clearing; the AIC then fiercely incinerated three bulldozers, and damaged the fourth. In addition, protesters also destroyed a number of rubber saplings. The AIC staged violent protest because they intuitively perceived that, without forceful pressure, the company would not suspend their activities to solve the problem and to address the AIC's demands.

The people thought that, this company, if we did not forcefully put pressure on it, it would not solve the problem. The people were then outraged. After violently throwing stones at the

\footnotetext{
$9 \quad$ P03 (see the Appendix).

$10 \quad$ P05 (see the Appendix).

$11 \quad$ P03 (see the Appendix).
} 
commune office's roof, we organised our force to burn down the tractors and bulldozers because the company did not listen to the suggestions of the villagers. ${ }^{12}$

Even though policemen and armed forces, who were hired to protect the company's property, were observing the violent protest, they took no action to disperse the outraged protest. They instead begged the protesters not to destroy the property of the companies.

We saw the policemen went with the villagers but they did not do anything ... the policemen begged and apologised to the villagers to stop burning and destroying. This is an outraged act of the villagers. It was because the commune councils and provincial authorities did not solve the problem. The violence erupted because of the lack of a detailed study and consultation with the villagers. ${ }^{13}$

Overall, non-institutional tactics employed by the AIC generated significant pressure directly on the company, and indirectly on the government. According to the law on peaceful assembly (2009), violent protest is illegal in Cambodia. If violent protests are organised, the concerned authorities are automatically authorised to crack down or take any suppressive measures. In addition to this law, theory likewise claims that violent protest tends to face severe repression (Goldstone and Tilly, 2001). However, neither the government, nor the company's guards took immediate measures against the violent protest. The AIC claimed that the company violently destroyed their properties without prior consent and/or consultation; thus, the indigenous communities were victims, ${ }^{14}$ not the company.

\section{Government responses: A combination of light repression and moderate concession}

Theoretically, a government can choose repression, concession, tolerance or a combination of concession and repression in response to a movement. In this case, the government, as an intermediary, prefers a combination of concession and repression, but repression tends to be light, while concession tends to be moderate. To repress, the government and company used

\footnotetext{
12 P05 (see the Appendix).

13 P05 (see the Appendix).

$14 \quad$ P05 (see the Appendix).
} 
the judicial system to retaliate against the indigenous communities' violent protest. On 12 January 2009, policemen and the provincial court, based on complaints by the company, arrested three representatives of the AIC and summoned another three representatives. These representatives were going to be charged of robbery and arson; however, due to persistent protest of the indigenous communities in front of the provincial court, the six representatives were released the same day. However, the release was on bail; if they spoke to the media, human rights groups (NGOs), or held violent protests again, they would be arrested and imprisoned. This was done to intimidate the ringleaders and protesters not to stage future protests. The government, however, claimed that the representatives were just summoned to be interrogated and, if the government had arrested the representatives, they would had to be charged for the destruction of the company's property.

To concede, after the violent protest, the government actively started re-enforcing existing regulations, such as the sub-decree on ELCs, an Environmental Impact Assessment (EIA), and acknowledging its malfeasance. In doing so, the government acted as a mediator to re-enforce its regulations, as claimed by Soule (2009). In regulatory theory, there are five levels of regulatory enforcement strategies-persuading, warning, monetary penalising, criminal charging, and revoking licenses - to be employed to ensure regulatory compliance (Ayres and Braithwaite, 1992). As an initial stage of enforcement, the government, in this case, negotiated with the company to re-fulfil regulatory requirements and to mitigate the adverse socio-economic impacts, as claimed by the AIC.

We had not done anything that was strict or forceful to the company, not at all ... In practice, the provincial authorities, concerned provincial departments, village and commune heads, mediated the conflict. This mediation did not mean that we put pressure on the company to solve the problem at all ... All in all, the protest of the villagers against the company was correct ... ${ }^{15}$

As a concession, the government then formulated a tripartite committee, which consisted of government officials (local authorities, provincial sectoral departments), the company, and the representatives of the AIC, to mitigate adverse impacts. The committee identified and demarcated the overlapping farmland, rice paddies, and other crop plantations of the 
indigenous families. With the overlapping area identified and demarcated, the committee introduced three options to address the claims of the indigenous families: cash compensation, land swaps and joint-rubber plantation and development ${ }^{16}$ (see mitigations and development section). Besides this, the company also agreed to mitigate the other adverse impacts claimed by the AIC.

Another applicable concession of the government was the Prime Minister's (PM) Subdecree on a moratorium on ELCs. On 7 May 2012, a month and a year before the commune councils and national assembly elections in 2012 and 2013, respectively, the PM issued (in Circular No. 001) a moratorium to temporarily suspend granting new ELCs (Subedi, 2012). The reason behind this regulatory concession was to attract the votes of those ELCs with affected communities and families. If there was no such intervention, the ruling party of the PM would be at stake if large-scale social protests were to happen throughout the country (see Footnote 17). This moratorium was applicable to most of ELCs, granted to both domestic and foreign investors, that induced adverse impacts. The issuance aimed at revoking inactive and exploitive ELCs, solving land disputes between the affected communities and concessionaires by introducing a "leopard skin policy" and issuing private land titles for the rightful claimants. I.e., lands that overlap with concession areas have to be ceded out (like leopard skin) and be officially returned with the land title to the rightful claimants (in this case, the villagers). To do so, numerous students from different local universities were asked for assistance. The moratorium on ELCs proved that the government re-enforced its regulations and conceded according to not only the claims of AIC in this rubber contention, but also other aggrieved communities in the country. ${ }^{17}$

\section{Company responses}

As explained in the theoretical section, the responses of the company rely on the government responses. To respond to the AIC and be in line with the government's concession, the company conceded by complying with the relevant regulations, mitigating adverse impacts and adopting self-regulation.

\footnotetext{
$16 \quad$ P01, P05 and P10 (see the Appendix).

17 During the indigenous communities' movements, there were several other movements or protests orchestrated by other ELC-affected communities in the country.
} 


\section{Regulatory compliance}

To comply with the government's re-enforcement, a local consulting company was hired to conduct full a Social and Environmental Impact Assessment (SEIA). ${ }^{18}$ The SEIA was concluded in September 2010 but local NGOs and the AIC alleged that the quality of the SEIA was insufficient, and that there were gaps between the mitigation plans and the actual practices. ${ }^{19}$ Despite the criticism, both the company and the government claimed that the company had done better in terms of regulatory compliance, compared to the other ELC companies in Cambodia. ${ }^{20}$

We know that we are in the foreign country ... All the regulations and the laws exist. For example, here in Cambodia, one company is allowed to have around 10,000 hectares of economic land concession. We know that, we respect that ... We just see that other companies do not do the same ... they have more than 40,000 hectares. I do not know how they did that, with the rules that exist in the country. ${ }^{21}$

In addition, the company complied with the ELC moratorium. As the students arrived at the concession area, they ceded about 300 hectares from the concession area to the rightful claim of the villagers. ${ }^{22}$ The company claimed that it was unfair to them because the villagers always wanted land in various areas. Not having been informed and consulted beforehand, the company claimed that the demarcation of the students was not conducted in a systematic way.

After the declaration of Prime Minister Hun Sen, suddenly there were new people that said they have a piece of land there but they could not prove it. The students did a lot of

\footnotetext{
$18 \quad$ P09 (see the Appendix).

19 P07 (see the Appendix).

$20 \quad$ P10 (see the Appendix).

$21 \quad$ P09 (see the Appendix).

22 Rightful claim is assessed in terms of being able to prove having land with crop plantations and other cultivation.
} 
demarcation inside the concession area. In total, they cut out 300 hectares. But not in the area that I planted but some are around the rivers. ${ }^{23}$

The company nevertheless ignored the carving since the students carved only land located along the river's edge and vacant land where the company had not planted rubber. Yet, the moratorium, due to the lack of methodological enforcement, adversely affected not only the company, but also the communal land (collective land ownership) of the indigenous communities (see historical background), which is not subject to be split into individual land ownership. Upon receiving individual land titles, a number of indigenous families sold their land to Khmer or Vietnamese in Bousra commune. Although the moratorium was, in fact, quickly enforced to maintain the support of these families in the upcoming elections in May 2012 and July 2013, it also benefited those affected families.

\section{Mitigations and development}

To mitigate the adverse impacts claimed by the AIC, the company carried out several activities. First, to compensate for some parts of the worship forest that were razed, the company celebrated with a sacrificial ceremony by killing buffalo (which costs between US\$300 to US\$500), offering indigenous people's wine (about US\$100 for few jars), and other traditional dances, to console the spirit of the forest. ${ }^{24}$ Second, the company conserved not only the remaining worship forest and cemeteries, but also the forest along the river's edge. This would help indigenous communities have access to NTFPs for their livelihoods. Also, the forest located along the river's edge would also help protect against soil erosion and landslides.

Third and last, following several discussion and negotiation meetings, the tripartite committee came up with three options to compensate and develop the livelihoods of the AIC. The first option was cash compensation or selling the land to the company. The company agreed with the government to compensate in cash about US\$200-250 per hectare. Each indigenous household received a different price based on their actual type of land and plantations. To compensate for perennial fruit trees, such as cashew nuts, mangoes, jackfruit,

\footnotetext{
$23 \quad$ P09 (see the Appendix).

$24 \quad$ FDG1 (see the Appendix).
} 
etc., the company paid about US\$2.50 per fruit tree. However, a fruit tree was paid for only if it bore fruit at the time of company's land clearing. Approximately 350 households opted for cash compensation. Nevertheless, some indigenous people complained that they were forced to accept cash compensation or to sell their land to the company, but the government rejected this allegation. ${ }^{25}$ Some of the AIC further claimed that the cash compensation was too cheap, and that they could not acquire another plot of land for cultivation. Despite the AIC's accusation, the government and the company affirmed that cash compensation was paid based on current land's market price at that time. ${ }^{26}$

The second option was joint-rubber plantation and development. The company allocated plots of land to the indigenous families to plant rubber. In addition to free technical assistance, the company offered fertilisers and replacement rubber saplings as loans. The families who opted for this option have to repay the loan upon tapping latex from the $9^{\text {th }}$ to the $20^{\text {th }}$ years. The latex can be sold at market price to the company. As a result, the company allocated about 300 hectares to a number of indigenous families who chose joint-rubber plantation schemes, and signed 60-year agreements with the company. Still, some of the participant families complained that the government and company confiscated their land, and leased it back to them for 60 years. Thus, they are ultimately not the owners of their land either. The company asserted that, it was beyond their capability since it was awarded only a 70-year concession period, not a life-long concession. The land belongs to the government, not the company. ${ }^{27}$ Because maintaining rubber trees needed intensive care and full-time labour, some families were not happy and, as of late 2013, they quit and secretly sold plots of rubber trees at about US\$1,500 to US\$2,000 per hectare to Khmer people, either from within Bousra commune or Phnom Penh city.

The third option was a land swap. The company reserved land in another location to exchange with the indigenous families who lost land to the concession. None of the affected families opted for this option since the reserved land was an outcrop area, and far from villages. ${ }^{28}$ The reserved land was located outside the concession area since the government and company perceived that, having indigenous families' land mixed with the rubber

\footnotetext{
$25 \quad$ P10 (see the Appendix).

$26 \quad$ P09 (see the Appendix).

$27 \quad$ P09 (see the Appendix).

28 FDG1 and FDG2 (see the Appendix).
} 
plantation areas, would cause further troubles, such as fire, damaging rubber trees and security. ${ }^{29}$

Other than the above, and to deal with livelihood concerns, the company motivated the indigenous people to work in their rubber farm. The government and company claimed that they created jobs, and employed a thousand indigenous people in Bousra commune. Jobs, to a lesser extent, compensated an equivalent amount of income they used to earn from collecting and selling NTFPs. Those indigenous families with higher education and skills were able to upgrade their livelihood better than those unskilled workers. ${ }^{30}$

\section{Codes of conduct and corporate responsibility}

To cope with other social impacts, the company regulated itself. Self-regulation, as discussed in the theoretical section, illuminates the autonomy of the rubber company from the local partner and the government. This is quite different compared to those joint ventures whose shareholders, such as powerful elites, officials and politicians, influence the process of decision making either to concede to the demands of affected communities or to self-regulate. According to FIDH (2011), the company developed its own Codes of Conduct (CoC) in 2009, after encountering the AIC movement, and being taken over by the foreign company (Sophia). The $\mathrm{CoC}$ is to be complied with by employees, entities of the group, as well as the company's suppliers and consultants. Thus, the $\mathrm{CoC}$ is a by-product of the AIC movement in Bousra commune. The $\mathrm{CoC}$ consists of non-discrimination in the workplace, respecting human rights, working conditions, sexual harassment, child and forced labour, and corruption. $^{31}$

We have our company standard that is quite strict ... I do not think you can find other companies that are doing the same ... how do they deal with the population? ... What they do is, they take the bulldozers and kick the people outside ... For us, it is our social responsibility to the population. ${ }^{32}$

\footnotetext{
$29 \quad$ P09 and P10 (see the Appendix).

$30 \quad$ FDG1(see the Appendix).

$31 \quad$ P09 (see the Appendix).

32 P09 (see the Appendix).
} 
To comply with its $\mathrm{CoC}$, the company constructed accommodation for its employees and provided a health service to both employees and non- and regular workers. Besides its social responsibilities, both the government and the AIC acknowledged that the company had done a lot of community development work in Bousra commune. Their focus was on health, education and infrastructure development. Annually, the company maintained and improved roads inside Bousra commune. For education and health, the company renovated two primary schools' classrooms, supported school materials, teachers' salaries and materials for a health centre. Like elsewhere, however, the AIC complained that these corporate social activities generated a minimal contribution to livelihood improvement of the affected indigenous communities. $^{33}$

\section{Outcomes of the movement of indigenous communities}

This section compares the demands and the actual outcomes obtained by the AIC, especially after the tactical escalation to non-institutional tactics. To reiterate, AIC movements succeed only when the government and company fully or moderately address demands to a certain level of satisfaction of the AIC. Based on the responses of the government and company, it is arguable that AIC movements achieve most of their demands. To recap, the AIC achieved four out of five expected socio-economic outcomes.

First, the company complied with the government, as well the demands of the AIC by conducting an SEIA and carving land from the concession area for the AIC. Second, the government and company successfully dealt with the worship forest by conserving and celebrating sacrificial ceremonies. Third, to mitigate livelihood and land issues, the company offered cash compensation, and introduced joint-rubber plantations to improve livelihoods of the AIC, in addition to employing indigenous people. Last, to cope with the business environment in Cambodia and to maintain its reputation in the international market arena, the company regulates itself by developing codes of conduct and implemented corporate social responsibility. As explained above, codes of conduct is an independent decision making of the company and also a byproduct of movements of the AIC. 
However, the government and company failed to clearly address the violation of indigenous and human rights. Since there is no clear mechanism of addressing human rights and the rights of indigenous communities in Cambodia, the government and company claimed that they had addressed most of the issues. If the issues were not dealt with, the AIC movements would otherwise endure. In spite of this contested argument, it can be concluded that the AIC movement succeeded because they achieved most of their demands. Most of the affected indigenous families felt satisfied with the outcomes, though a few affected families were not satisfied. ${ }^{34}$ These achievements would foster better performance of the company and government towards the socio-economic sustainability of indigenous communities in the cash economy era.

\section{Conclusion}

This paper has fleshed out the dynamics and outcomes of indigenous communities' movements targeting an agro-industrial investment, which was endorsed by the government. Initially, the indigenous communities targeted the government by employing institutional tactics, such as peaceful protest and filing petitions with several government institutions in the hope of influencing the government to regulate the company. Since these tactics leveraged no significant influence, the indigenous communities shifted to non-institutional tactics, in which they employed violent protest: burning and destroying bulldozers and tractors to exert influence directly on the company, and indirectly on the government. As mechanisms of response, the government chose a combination of light repression and moderate concession. Initially, and to repress, the government selectively detained some protesters, who were thereafter released on bail. Later, and to concede, the government negotiated with the company and re-enforced relevant regulations (sub-decrees on ELCs, and an environmental impact assessment). The shift from repression to concession by the government is to some extent influenced by the national political environment, especially the commune councils and national assembly elections in 2012 and 2013, respectively. Compelled by the movements of the indigenous communities, switching to concession was

$34 \quad$ FDG1 and FDG2 (see the Appendix). Due to differing expectations of the indigenous people, some families were not happy with the solution. 
thus opted to placate the communities to vote for the ruling party. These concessive responses then shaped the company responses.

As a mechanism of response, the company: (i) complied with government's regulatory re-enforcement by conducting social and environmental impact studies, and returning the overlapping land to the communities; (ii) mitigated adverse socio-economic impacts; and (iii) self-regulated by developing codes of conduct, and implementing corporate social responsibility to harmonise and ensure long-term investment in the indigenous communities. With these mechanisms of response, indigenous communities achieved most of their demands. These positive responses would contribute to the socio-economic sustainability of the indigenous communities and their future development. This large-scale rubber plantation would contribute to improved economic conditions of the indigenous communities, but some aspects of their culture (such as belief, worship, relationships, traditional cultivation) would be altered by the influx of economic migrants and other development. Conservation of the forest and other natural resources, which are present and future sources of livelihood of the indigenous people who have not adapted themselves to the current cash economy are at stake if there is no effective management and enforcement of regulations (Sokphea, 2015).

With the above responses of the government and company, and results of movements, it is arguable that the tactical escalation of indigenous communities from institutional to noninstitutional tactics exerted indirect influence on the government in the hope of regulating the company. These movements furthermore shaped the behaviour of the company, which is operating in a host country with lax and uncertain regulatory enforcement, to behave in a more sustainable way towards the indigenous communities. This experience might inspire future social movements of indigenous communities elsewhere if public consultation, social and environmental impacts and other regulations are not effectively enforced by the government or complied with by the private companies. In pursuit of sustainable development and common interests of the communities, these movements would to some extent tackle exploitative and rent-seeking investments of foreign companies and the local politico-commercial elites of this regime.

Regardless of other factors explaining outcomes (either success or failure), this study, corroborating with Cai (2010), Chenoweth and Stephan (2011), Gamson (1990), Steedly and Foley (1979) and Stephan and Chenoweth (2008), argues that the use of tactics has certain influence on the targets to address the aggrieved groups' demands. In this case, non- 
institutional (violent) tactics, however, tend to be more effective than the institutional tactics. This has significant implications not only for tactical employment of (new) social movements, but also contention that involves the government, the indigenous communities and the private company, which has not been well discussed in contemporary social movement studies.

\section{Acknowledgement and disclaimer}

Data presented in this paper were collected as part of the author's doctoral research, which was supported by Faculty of Arts of the University of Melbourne. The author would like to thank Kate Macdonald and Andrew Walter for their insightful comments on earlier draft of this paper.

\section{References}

ADHOC (The Cambodian Human Rights and Development Association) (2013) A Turning Point? Land, Housing and Natural Resources Rights in Cambodia 2012. Phnom Penh: ADHOC.

Ayres, Ian and John Braithwaite (1992) Responsive Regulation: Transcending the Deregulation Debate. New York, Oxford: Oxford University Press.

Backstrom, Maria, Jeremy Ironside, Gordon Paterson, Jonathan Padwe and Ian G. Baird (2007) Case Study: Indigenous Traditional Legal Systems and Conflict Resolution in Ratanakiri and Mondulkiri. Bangkok: United Nations Development Programme.

Baird, Ian G. (2008) "Various Forms of Colonialism: The Social and Spatial Reorganization of the Brao in Southern Laos and Northeastern Cambodia”. Ph.D. Dissertation, University of British Columbia.

Buechler, Steven M. (1995) "New social movement theories". The Sociological Quarterly 36(1): 441-64. 
Burstein, Paul (1999) "Social movements and public policy", in Marco Giugni, Doug McAdam and Charles Tilly (eds.) How Social Movements Matter. Minneapolis, London: University of Minnesota Press, Pp. 3-21.

Cai, Yongshum (2010) Collective Resistance in China: Why Popular Protests Succeed or Fail. Stanford, California: Stanford University Press.

CDC (Coucil for Development of Cambodia) (2010) Cambodian Investment Board: Projects by Sector Approved. Phnom Penh: Councils for Development of Cambodia.

Chenoweth, Erica and Maria J. Stephan (2011) Why Civil Resistance Works: The Strategic Logic of Nonviolent Conflict. New York: Columbia University Press.

Colm, Sara (1996) The Highland Minorities and the Khmer Rouge in Northeastern Cambodia 1968-1979. Phnom Penh: Document Center of Cambodia.

Cress, Daniel M. and David A. Snow (2000) "The outcomes of homeless mobilization: The influence of organization, disruption, political mediation, and framing". American Journal of Sociology 105(4): 1063-104.

FIDH (International Federation for Human Rights) (2011) Cambodia Land Cleared for Rubber, Rights Bulldozed: The Impact of Rubber Plantations by Socfin-KCD on Indigenous Communities in Bousra, Mondulkiri. International Federation for Human Rights.

Gamson, William A. (1990) The Strategy of Social Protest. Belmont, CA: Wadsworth Publication.

George, Alexander L. and Andrew Bennett (2005) Case Studies and Theory Development in the Social Sciences. Cambridge, London: MIT Press.

Giugni, Marco (1998) "Was it worth the effort? The outcomes and consequences of social movements". Annual Review of Sociology 24(1998): 371-93.

_ (1999) "How Social Movement Matter: Past Research, Present, Future Developments", in Marco Giugni, Doug McAdam and Charles Tilly (eds.) How Social Movements Matter. Minneapolis, London: University of Minnesota Press, Pp. xiii-xxxiii.

Global Witness (2007) Cambodia's Family Trees: Illegal Logging and the Stripping Public Assets by Cambodia's Elites. Washington, D.C.: Global Witness Publishing, Inc.

Goldstone, Jack A. and Charles Tilly (2001) “Threat (and opportunity): Popular action and state response in the dynamics of contentious action", in Ronald R. Aminzade, Jack A. Goldstone, Doung McAdam, Elizabeth J. Perry, William H. Sewell, Sidney Tarrow 
and Charles Tilly (ed.) Silence and Voice in the Study of Contentious Politics. Cambridge, NY: Cambridge University Press, Pp. 179-94.

Gusfield, Joseph R. (1984) The Culture of Public Problems: Drinking-driving and the Symbolic Order. Chicago: University of Chicago Press.

Hall, F. Melvin (1995) Poor People's Social Movement Organizations: The Goal is to Win. Westport, London: Greenwood Publishing Group.

Isaac, Larry and William R. Kelly (1981) "Racial insurgency, the state, and welfare expansion: Local and national level evidence from the postwar United States". American Journal of Sociology 86(6):1348-86.

Keating, Neal B. (2013) "Kuy alterities: The struggle to conceptualise and claim Indigenous land rights in neoliberal Cambodia”. Asia Pacific Viewpoint 54(3): 209-322.

King, Brayden G. (2008) "A political mediation model of corporate response to social movement activism". Administrative Science Quarterly 53(3): 395-421.

Klandermans, Bert and Sidney Tarrow (1998) "Mobilization into Social Movement: Synthesizing European and American Approaches", in Bert Klandermans, Hanspeter Kriesi and Sidney Tarrow (ed.) International Social Movement Research. Greenwich, CT: JAI Press, Pp. 1-38.

Marx, Gary T. and Doug McAdam (1994) Collective Behavior and Social Movements: Process and Structure. Englewood Cliffs, NJ: Prentice Hall.

McAdam, Doug (1983) "Tactical innovation and the pace of insurgency". American Sociological Review 48(6): 735-54.

— (1988) Freedom Summer. New York: Oxford University.

— (1999) Political Process and the Development of Black Insurgency, 1930-1970. Chicago, London: University of Chicago Press.

McAdam, Doug and Sidney Tarrow (2000) "Nonviolence as contentious interaction". PS: Political Science and Politics 33(2): 149-54.

McAdam, Doug, Sidney Tarrow and Charles Tilly (2001) Dynamics of Contention. Cambridge, NY: Cambridge University Press.

McAndrew, John P. and Oeur Il (2009) "Access to natural resources: Case Studies of Cambodian Hill Tribes", in Perera Jayantha (ed.) Land and Cultural Survival: The Communal Land Rights of Indigenous People in Asia. Manila: Asian Development Bank, Pp. 93-124. 
Milne, Sarah (2013) "Under the leopard's skin: Land commodification and the dilemmas of indigenous communal title in upland Cambodia”. Asia Pacific Viewpoint 54(3): 32339.

Moser, Titus (2001) "MNCs and sustainable business practice: The case of the Colombian and Peruvian petroleum industries". World Development 29(2): 291-309.

Ngov, Penghuy (2011) “ASEAN Economic Integration and Cambodia' Industrial Policies”. Ritsumeikan International Affairs 10(2010): 67-94.

O'Brien, Kevin J. and Lianjiang Li (2006) Rightful Resistance in Rural China. Cambridge, NY: Cambridge University Press.

Offe, Claus (1985) "New Social Movements: Challenging the Boundaries of Institutional Politics". Social research 52(4): 817-68.

Pichardo, Nelson A. (1997) "New social movements: A critical review". Annual Review of Sociology 23(1): 411-30.

RGC (Royal Government of Cambodia) (2005) Sub-decree on Economic Land Concessions. Phnom Penh: Royal Government of Cambodia.

- (2009) Sub-decree on Procedures of Registration of Land of Indigenous Communities. Phnom Penh: Royal Government of Cambodia.

Royal Decree (2009) Law on Peaceful Assembly. Phnom Penh: Royal Government of Cambodia.

— (2001) Land Law. Phnom Penh: Royal Government of Cambodia.

— (2002) Forestry Law. Phnom Penh: Royal Government of Cambodia.

Rucht, Dieter (1988) "Themes, logics, and arenas of social movements: A structural approach", in Bert Klandermans, Hanspeter Kriesi and Sidney Tarrow (ed.) International Social Movement Research. Greenwich, CT: JAI Press, Pp. 305-28.

Schurman, Rachel (2004) 'Fighting 'Frankenfoods': Industry Opportunity Structures and the Efficacy of the Anti-Biotech Movement in Western Europe”. Social Problems 51(2): 243-68.

Soule, Sarah A. (2009) Contention and Corporate Social Responsibility. New York: Cambridge University Press.

_ (2012) "Social Movements and Markets, Industries, and Firms". Organization Studies 33(12): 1715-33. 
Steedly, Homer and John W. Foley (1979) "The success of protest groups: Multivariate analyses". Social Science Research 8(1): 1-15.

Stephan, Maria J. and Erica Chenoweth (2008) "Why civil resistance works: The strategic logic of nonviolent conflict". International Security 33(1): 7-44.

Subedi, Surya P. (2012) "Human Rights Analysis of Economic and other Land Concession in Cambodia: Report of the Special Rapporteur on the Situation of Human Rights in Cambodia". Available

at: http://www.ohchr.org/Documents/HRBodies/HRCouncil/RegularSession/Session21/A -HRC-21-63-Add1_en.pdf\%3E\%3E (accessed on 1 March 2014).

Tarrow, Sidney (1994) Power in Movement: Social Movements, Collective Action and Mass Politics in the Modern State. Cambridge: Cambridge University Press.

— (1998) Power in Movement: Social Movements and Contentious Politics. Cambridge, NY: Cambridge University Press.

Tilly, Charles (1978) From Mobilization to Revolution. McGraw-Hill New York.

Un, Kheang (2009) 'China's Foreign Investment and Assistance: Implications for Cambodia' Development and Democratization”. Peace and Conflict Studies 16(2): 65-81.

Van Dyke, Nella, Sarah A. Soule and Verta A. Taylor (2005) "The targets of social movements: Beyond a focus on the state". Research in Social Movements, Conflicts and Change 25: 27-51.

Sokphea, Young (2015) Contention and Corporate Sustainability Practices in the Cambodian Agricultural Sector. Working Paper 166. Hong Kong, SAR: Southeast Asia Research Centre of City University of Hong Kong.

Walker, Edward T., Andrew W. Martin and John D. McCarthy (2008) "Confronting the State, the Corporation, and the Academy: The Influence of Institutional Targets on Social Movement Repertoires”. American Journal of Sociology 114(1): 35-76.

Wilson, John (1973) Introduction to Social Movements. New York: Basic Books.

Wood, Lesley J. (2004) "Breaking the bank and taking to the streets: How protesters target neoliberalism". Journal of World-systems Research 10(1): 69-89. 


\section{Appendix: List of participants}

\begin{tabular}{|l|l|l|}
\hline Code & Title & Interviewed \\
\hline P01 & Ex- Commune Chief & 19 Nov 2013 \\
\hline P02 & Village Chief 1 & 19 Nov 2013 \\
\hline P03 & Villagers Representative 1 & 18 Nov 2013 \\
\hline P04 & Villagers Representative 2 & 17 Nov 2013 \\
\hline P05 & Villagers Representative 3 & 18 Nov 2013 \\
\hline P06 & Deputy Director of Provincial Department of Agriculture & 23 Dec 2013 \\
\hline P07 & Provincial Manager-NGO & 08 Jan 2014 \\
\hline P08 & Village Chief 2 & 18 Nov 2013 \\
\hline P09 & CEO of ELCs & 23 Dec 2013 \\
\hline P10 & Deputy Provincial Governor & 10 Jan 2014 \\
\hline P11 & Village Chief 3 & 18 Nov 2013 \\
\hline P12 & Independent Researcher & 26 Nov 2013 \\
\hline P13 & Lecturer & 02 Jan 2014 \\
\hline P14 & Independent Researcher & 02 Dec 2013 \\
\hline P15 & Deputy Provincial Manager-NGO & 07 Jan 2014 \\
\hline P16 & ELCs Officer of Ministry of Agriculture & 03 Dec 2013 \\
\hline FDG1 & Focus Group Discussion (FDG) in Pu Toeut Village & 17 Nov 2013 \\
\hline FDG2 & Focus Group Discussion in La Mesh Village & 17 Nov 2013 \\
\hline
\end{tabular}

